\title{
Photo-oxidation of pre-treated palm oil mill Effluent using cylindrical column immobilized photoreactor
}

\author{
Mohammed Haji Alhaji ${ }^{a, b, *}$, Khairuddin Sanaullah ${ }^{a}$, Shanti Faridah Salleh ${ }^{a}$, \\ Rubiyah Baini ${ }^{a}$, Soh Fong Lim ${ }^{a}$, Andrew Ragai Henry Rigit ${ }^{c}$, \\ Khairul Anwar Mohamad Said ${ }^{a}$, Afrasyab Khan ${ }^{a}$ \\ a Department of Chemical Engineering and Energy Sustainability, Faculty of Engineering, Universiti Malaysia Sarawak (UNIMAS), Malaysia \\ ${ }^{\mathrm{b}}$ Nigerian Institute of Leather and Science Technology Zaria-Nigeria \\ ${ }^{\mathrm{c}}$ Department of Mechanical and Manufacturing Engineering, Faculty of Engineering, Universiti Malaysia Sarawak(UNIMAS), Malaysia
}

\section{A R T I C L E I N F O}

\section{Article history:}

Received 14 December 2017

Received in revised form 8 March 2018

Accepted 23 April 2018

Available online 25 April 2018

\section{Keywords:}

Kinetic studies

Organic pollutant indicators

Palm oil mill effluent

Photodegradation

Titanium dioxide

\begin{abstract}
A B S T R A C T
Photooxidative degradation of pre-treated Palm oil mill effluent for removal of chemical oxygen demand, biological oxygen demand and color by $\mathrm{UV} / \mathrm{TiO}_{2}$ system has been investigated in a cylindrical glass photoreactor whose outer surface has been coated with titanium dioxide whereas the UV source has been placed inside the glass tube. The removal of these pollutants indicators has been found to follow pseudofirst-order kinetics and hence the electrical energy per order $\left(E_{E O}\right)$ figure-of-merit is used to calculate approximately the electrical energy efficiency of the advanced oxidation process system. The higher dissolved oxygen $(10 \mathrm{mg} / \mathrm{L})$, lower initial concentration $(6 \mathrm{mg} / \mathrm{L})$ and acidic medium $(\mathrm{pH}=3)$ have been found favorable to the photocatalytic degradation of palm oil mill effluent.
\end{abstract}

(C) 2018 Institution of Chemical Engineers. Published by Elsevier B.V. All rights reserved.

\section{Introduction}

The degradation of POME through the determination organic pollutant indicators (OPIs) such as chemical oxygen demand COD, BOD and color present in a typical palm oil mill effluent (POME) has emerged as an area of interest for research among environmental industrialists and scientists, the reason being that the palm oil production for local consumption and source of foreign exchange among emerging economies of countries such as Malaysia has taken higher dimension. This higher production level has also increase the volume of untreated POME that has been discharged from the processing mills. Though, all this processing mills have treatment facilities to treat this POME before discharge, there are still presence of harmful organic pollutants in the POME that have reduced to a great deal environmental activities (such as farming) involving man (Pasieczna-Patkowska et al., 2010; Wu et al., 2010; Rizzo et al., 2013; Ding and Bao, 2014; Othman et al., 2014; Garcia-Nunez et al., 2016). Hence, their effective removal from POME before disposal or discharge into the environment is of upmost important

\footnotetext{
* Corresponding author.

E-mail addresses: 15010116@siswa.unimas.my, hajialhaji2000@gmail.com (M.H. Alhaji).
}

not only for its decontamination alone but also to safeguard the environment against ecological disaster that could be detrimental to the healthy survival and well-being of the occupants (man, plants and animals) of mother earth. Moreover, traditional biological (Aerobic or Anaerobic) treatments are ineffective for destroying organic pollutants (Ops) due to the presence of complex molecular configuration of their atoms, high noxiousness and their poor biodegradability. Similarly, conventional physiochemical methods (coagulation, adsorption, reverse osmosis flocculation, extraction or evaporation) only transform these OPs from one phase into the other without rescinding them (Alhaji et al., 2016; Alhaji et al., $2017 \mathrm{a}, \mathrm{b}, \mathrm{c})$. Therefore, there is a need to devise appropriate remediation technologies that will be capable to completely mineralize OPs into environmental friendly compounds, which when being discharged into the environment, they will pose no threat to the survival of man, plants or animals.

Advanced oxidation processes (AOPs) employing mainly titanium dioxide catalyst can become useful to degrade organic pollutants present in POME efficiently and economically. One of such AOPs that has been widely employed for the removal of wide of range of $\mathrm{OP}$ in wastewater in the past decades has been heterogeneous photocatalysis. These technology has been adequately reported in various scientific(Fujishima et al., 2000; Le et al., 2012). Titanium being inexpensive, non-toxic with high chemical sta- 